\title{
Incidental lingual thyroid with subclinical hypothyroidism: case report
}

Turki Abdul Kareem al Driweesh', Mohammad Mosa Mokhatrish ${ }^{1}$, Tahera Islam² ${ }^{2 *}$ and Khalid H. Al-Qahtani ${ }^{3}$

\begin{abstract}
Background: Lingual thyroid is a very rare pathological finding and is usually incidentally discovered. It occurs when a defect in embryogenesis gives rise to ectopic thyroid as tongue base mass. Majority of patients are asymptomatic. This clinical case highlights the importance of performing thyroid function tests for all lingual thyroid patients regardless of symptoms or clinical presentation.

Case presentation: We present a 25-year-old lady who presented with sub-mental abscess. A CT scan was performed to confirm the diagnosis. The CT scan confirmed submental abcess and incidentally discovered lingual thyroid along with absence of thyroid tissue in its normal pretracheal position. The patient denied any symptoms of hypothyroidism. But subsequent investigations revealed clinical hypothyroidism. She was started on substitutive hormone therapy and remains asymptomatic.
\end{abstract}

Conclusion: Lingual thyroid patients may remain asymptomatic with subclinical hypothyroidism. Hormone therapy needs to be initiated in these patients.

Keywords: Lingual thyroid, Hypothyroidism, Congenital anomaly, Ectopic thyroid, Case report

\section{Key messages}

Patients with hypothyroidism due to ectopic thyroid may remain symptom free and only come to attention after thyroid function test are carried out. Thyroid function tests are warranted whenever lingual thyroid is diagnosed irrespective of clinical presentation.

\section{Background}

Lingual thyroid is a rare embryological aberration resulting from the arrest of downward migration of the thyroid gland. Ninety percent of thyroid ectopia involves the lingual region [1]. Majority of patients are asymptomatic and are diagnosed incidentally through head and neck radiography. The most common presentation of symptomatic lingual thyroid is a mass in the midline at the base of the tongue. Depending on the size of the mass, some patients

\footnotetext{
* Correspondence: tahera@ksu.edu.sa

${ }^{2}$ College of Medicine and Research Center, King Abdul Aziz University Hospital, King Saud University, PO Box no-245, Riyadh 11411, Kingdom of

Saudi Arabia

Full list of author information is available at the end of the article
}

may present with more severe symptoms such as dysphagia, dysphonia, dyspnea, and hemorrhage [2].

The prevalence of lingual thyroid ranges from 1 in 100, 000 to 300,000 ; the prevalence is approximately 4 to 8 times higher in females than in males [2]. Thyroid tissue is absent in the normal location in $70-80 \%$ of patients with lingual thyroid, and approximately one third of patients are hypothyroid [2]. Frequently, in these patients, lingual thyroid is detected during the diagnostic investigation of subclinical hypothyroidism. Here, we report a woman who presented with submental abscess confirmed on CT scan, along with an incidental diagnosis of with lingual thyroid. Although the patient did not demonstrate any symptoms of hypothyroidism, further laboratory investigations revealed subclinical hypothyroidism. This clinical case highlights the importance of performing thyroid function tests for all lingual thyroid patients regardless of symptoms or clinical presentation.

(c) The Author(s). 2020 Open Access This article is licensed under a Creative Commons Attribution 4.0 International License, which permits use, sharing, adaptation, distribution and reproduction in any medium or format, as long as you give appropriate credit to the original author(s) and the source, provide a link to the Creative Commons licence, and indicate if changes were made. The images or other third party material in this article are included in the article's Creative Commons licence, unless indicated otherwise in a credit line to the material. If material is not included in the article's Creative Commons licence and your intended use is not permitted by statutory regulation or exceeds the permitted use, you will need to obtain permission directly from the copyright holder. To view a copy of this licence, visit http://creativecommons.org/licenses/by/4.0/. 


\section{Case presentation}

A 25-year-old woman visited the clinic with the complaint of submental swelling for 2 weeks. Skin rash and multiple cervical swelling preceded the submental swelling by 2 weeks. She had previously sought medical advice and prednisolone and antibiotics had been prescribed. Her rash improved but the submental swelling remained unchanged. Neck clinical examination showed a firm, nonmobile, nontender, $3 \times 4 \mathrm{~cm}$ submental mass. Apart from this, the otolaryngology examination was unremarkable. She had no other systemic complaints.

We suspected the presence of a submental abscess; accordingly, the patient was referred for head and neck contrast computed tomography (CT). The scan demonstrated submental fluid collection (approximately $2 \times 1 \mathrm{~cm}$ ) with rim enhancement; these results confirmed our diagnosis. The CT scan also revealed existence of an unusual lesion-a well-defined, rounded lesion mainly of hyperdense soft tissue density-in the midline of the base of the tongue. It measured around $2 \times 2 \mathrm{~cm}$. The CT scan showed small, internal hypodense areas that enhanced diffusely after administration of contrast. Along with these observations, the contrast $\mathrm{CT}$ failed to visualize normal thyroid density in the pre-tracheal area. These image findings were suggestive of ectopic thyroid at the

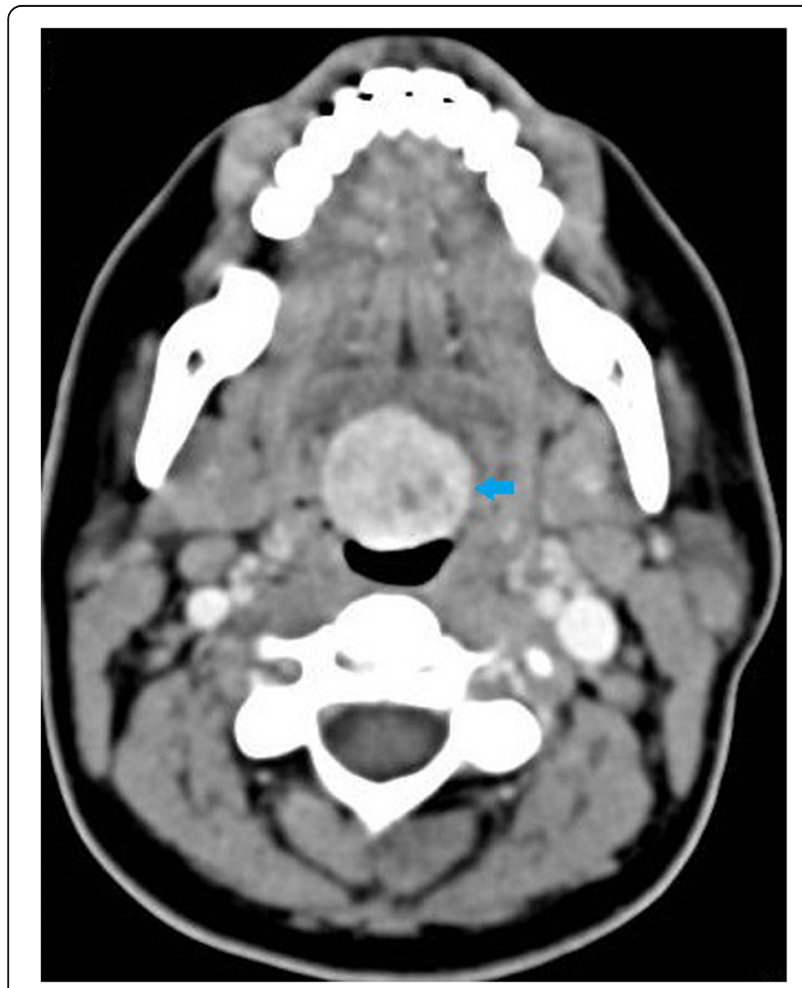

Fig. 1 Head and neck contrast-enhanced axial computed tomographic scan showing a hyperdense soft tissue density in the midline at the base of the tongue (arrow) tongue base, as shown in Figs. 1 and 2. This confirmed the diagnosis of a coexisting lingual thyroid. Considering the absence of normal thyroid tissue in the normal position, further investigations were recommended. A thyroid function panel revealed hypothyroidism based on the following results: thyroid-stimulating hormone level, $90.6 \mathrm{mIU} / \mathrm{L}$ (normal range, $0.25-5 \mathrm{mIU} / \mathrm{L}$ ); free triiodothyronine level, $4.09 \mathrm{pmol} / \mathrm{dL}$ (normal range, 3.95-9.5 pmol/dL); and free tetraiodothyronine level, $9.88 \mathrm{pmol} / \mathrm{L}$ (normal range, $10.3-25.8 \mathrm{pmol} / \mathrm{L})$. She was referred to an endocrinologist for her hypothyroidism.

The patient was admitted, and aspiration of the fluid collection was performed. Furthermore, she was started on intravenous antibiotics. Within a couple of days, the patient's condition improved dramatically; thus, she was discharged. We decided to manage the lingual thyroid conservatively and she was started on substitutive hormone therapy. Currently, she has regular follow-ups with the endocrinologists and remains euthyroid.

\section{Discussion}

The thyroid gland starts to develop at the 3rd week of gestation; development by descent along the thyroglossal tract to the final pre-laryngeal position is completed at the 7th week. This tract degenerates as the thyroid reaches its final position at the level of hyoid bone. Arrest of thyroid embryogenesis at any stage of descent gives rise to multiple anomalies including ectopic thyroid [3].

Lingual thyroid constitutes the majority of ectopic thyroid cases; however, remnants of thyroid tissue have been documented in different positions along the migration tract [4]. In almost $70 \%$ of patients, eutopic thyroid tissue was absent; however, few cases of dual thyroid have also been documented [1,5]. A considerable number of patients (up to $70 \%$ ) presented with hypothyroidism, similar to our patient. Surprisingly, some presented with hyperthyroidism [6]. Urgent intervention is required for patients presenting with dysphagia, dysphonia, dyspnea, or hemorrhage.

The diagnostic work-up for lingual thyroid includes CT, magnetic resonance imaging, technetium scanning, and fine needle aspiration [7]. Thyroid function tests are used to evaluate the functional status of the thyroid gland.

The treatment strategy for lingual thyroid is a controversial issue. In general, for asymptotic cases with normal thyroid status, patients can be monitored with frequent follow-ups. In case of hypothyroidism, like in our patient, thyroid replacement therapy is initiated, which further aims to simultaneously shrink the ectopic tissue [4]. Surgical intervention is reserved for failure of medical treatment, such as in case of compressive symptoms or bleeding masses. In some cases, lifelong hormone replacement may be needed. 


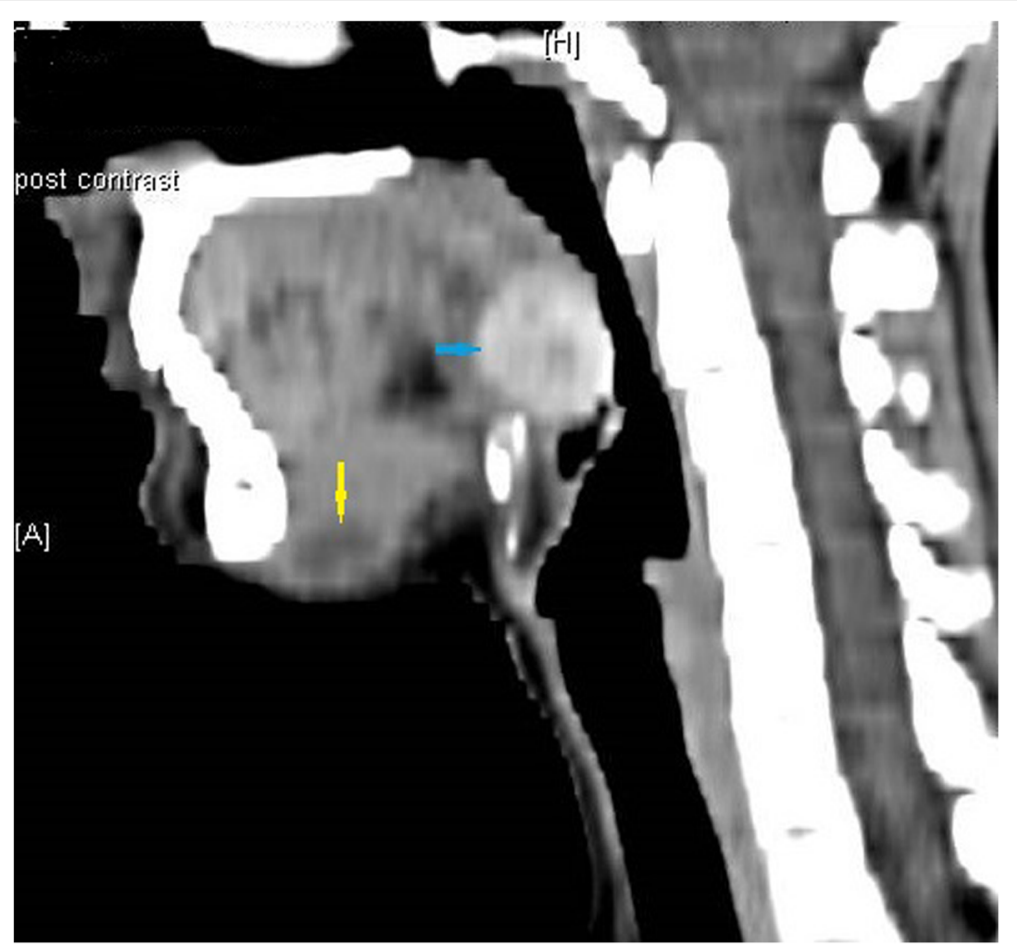

Fig. 2 Sagittal view of contrast-enhanced CT showing lingual thyroid: a well-defined, rounded, mainly hyper-dense soft tissue density at the base of the tongue (blue arrow); submental abscess (yellow arrow)

\section{Conclusions}

Lingual thyroid is a rare clinical entity. Patients may remain asymptomatic and are diagnosed incidentally even though there is biochemical evidence of hypothyroidism. Good knowledge of embryogenesis will result in proper diagnosis. Hormone replacement therapy with thyroxine should be started in apparently asymptomatic patients, when there is evidence of hypothyroidism. Patients should be monitored through follow-ups for the development of complications like dysphagia or dyspnea or, in very rare circumstances, carcinoma.

\section{Abbreviations}

CT: Computed tomography

\section{Acknowledgements}

Not applicable.

\section{Authors' contributions}

TD drafted the manuscript, approved the submitted version, is personally accountable for the author's own contributions, and ensured that questions related to the accuracy or integrity of any part of the work, even ones in which the author was not personally involved, are appropriately investigated, resolved, and the resolution documented in the literature. MM drafted the manuscript, approved the submitted version, is personally accountable for the author's own contributions, and ensured that questions related to the accuracy or integrity of any part of the work, even ones in which the author was not personally involved, are appropriately investigated, resolved, and the resolution documented in the literature. TI revised the article, is personally accountable for the author's own contributions, and ensured that questions related to the accuracy or integrity of any part of the work, even ones in which the author was not personally involved, are appropriately investigated, resolved, and the resolution documented in the literature. KQ is the treating consultant, revised the article, is personally accountable for the author's own contributions, and ensured that questions related to the accuracy or integrity of any part of the work, even ones in which the author was not personally involved, are appropriately investigated, resolved, and the resolution documented in the literature. All authors have read and approved the manuscript.

\section{Funding}

None

Availability of data and materials Not applicable.

Ethics approval and consent to participate Not applicable.

\section{Consent for publication}

Verbal consent was obtained from the patient for publication of this case report and accompanying images.

\section{Competing interests}

The authors declare that they have no competing interests.

\section{Author details}

'Department of Otolaryngology-Head \& Neck Surgery, College of Medicine, Prince Sattam University, Alkharj, Kingdom of Saudi Arabia. ${ }^{2}$ College of Medicine and Research Center, King Abdul Aziz University Hospital, King Saud University, PO Box no-245, Riyadh 11411, Kingdom of Saudi Arabia. ${ }^{3}$ Department of Otolaryngology-Head \& Neck Surgery, King Abdulaziz University Hospital, College of Medicine, King Saud University, Riyadh, Kingdom of Saudi Arabia. 
Received: 9 April 2020 Accepted: 20 May 2020

Published online: 26 August 2020

\section{References}

1. Kumar Choudhury B, Kaimal Saikia U, Sarma D, Saikia M, Dutta Choudhury S, Barua S et al (2011) Dual ectopic thyroid with normally located thyroid: a case report. J Thyroid Res. 2011:159703. https://doi.org/10.4061/2011/159703

2. Rahbar R, Yoon MJ, Connolly LP, Robson CD, Vargas SO, McGill TJ et al (2008) Lingual thyroid in children: a rare clinical entity. Laryngoscope. 118(7):1174-1179. https://doi.org/10.1097/MLG.0b013e31816f6922

3. Fiaschetti V, Claroni G, Scarano AL, Schillaci O, Floris R (2016) Diagnostic evaluation of a case of lingual thyroid ectopia. Radiol Case Rep. 11:165-170. https://doi.org/10.1016/j.radcr.2016.04.004

4. Amr B, Monib S (2011) Lingual thyroid: a case report. Int J Surg Case Rep. 2: 313-315. https://doi.org/10.1016/j.ijscr.2011.10.004

5. Khamassi K, Jaafoura H, Masmoudi F, Lahiani R, Bougacha L, Ben SM (2015) Ectopic lingual thyroid. Case Rep Pediatr. 2015:252357. https://doi.org/10. $1155 / 2015 / 252357$

6. Santangelo G, Pellino G, De Falco N, Colella G, D'Amato S, Maglione MG et al (2016) Prevalence, diagnosis and management of ectopic thyroid glands. Int J Surg. 28(Suppl 1):S1-S6. https://doi.org/10.1016/j.jisu.2015.12. 043

7. Castro PH, Volpato LE, Tramujas J, Borges AH (2016) Ectopic thyroid at the base of the tongue of a young patient. Case Rep Dent. 2016:9174970

\section{Publisher's Note}

Springer Nature remains neutral with regard to jurisdictional claims in published maps and institutional affiliations.

\section{Submit your manuscript to a SpringerOpen ${ }^{\circ}$ journal and benefit from:}

- Convenient online submission

- Rigorous peer review

- Open access: articles freely available online

- High visibility within the field

- Retaining the copyright to your article

Submit your next manuscript at $\boldsymbol{\nabla}$ springeropen.com 